\title{
cognitive science in moscow
}

\section{Anxiety and the Problem of "Inattentive" Animals in Water Maze Tests}

\section{Nina A. Bondarenko}

Foundation "Development of the pharmacology of emotional stress", Krasnogorsk, Moscow region, Russia

\begin{abstract}
Some reports have described the low reactivity of rats to a water-escape platform during their initial exposition to the Morris water maze or Cincinnati water maze, which impedes task acquisition. To assess the attention of rats to tactile stimuli, we measured the paw tactile reactivity in rats exposed to the original water "Extrapolation Escape Task" (EET). In this test, a rat tries to dive to escape from a plastic cylinder immersed into a water tank. Only rats with high trait anxiety demonstrated tactile neglect after their initial exposition to that water locomotion task. Previous EET training, but not novelty, motivation, the physical factors of water immersion, exercise or stress influence that effect. We propose that there is a distractor effect of the difficult diving task on ordinary tactile oriented behavior in anxious rats.
\end{abstract}

Correspondence: Nina A. Bondarenko, bondarenko52nina@gmail.com, 32 Schastlivaya ul., Opalikha district, Krasnogorsk city, 143444, Moscow region, Russia

Keywords: rat, Extrapolation Escape Task, tactile sensory stimulation, locomotion task, orienting behavior, attention, distractors, anxiety

Copyright $\odot$ 2017. Nina A. Bondarenko. This is an open-access article distributed under the terms of the Creative Commons Attribution License (CC BY), which permits unrestricted use, distribution, and reproduction in any medium, provided that the original author is credited and that the original publication in this journal is cited, in accordance with accepted academic practice.

Received 17 October 2017, accepted 26 December 2017.

\section{Introduction}

It is well known that rats and mice have an inborn tendency to seek solid ground when in water. But in experimental conditions (initial exposition to the Morris water maze, Cincinnati water maze, etc.) some animals do not respond to the hidden escape platform and instead swim away (Vorhees \& Williams, 2016; Weitzner et al., 2015). Those animals suffer a type of stress from being unable to escape: forced swim (FS) stress. It induces an immobility (floating behavior), often interpreted as a symptom of depressive-like behavioral despair, which influences spatial memory formation in water mazes (Drugan et al., 2013; de Kloet \& Molendijk, 2016; Ježek et al., 2010; Sandi et al., 1997). Many researchers recommend pushing the "inattentive" animal to the hidden platform to help it to escape. But this technique violates the equivalence of the experimental treatment for all individual animals under the given experimental condition (Vorhees \& Williams, 2016). Pre-training in the maze facilitates escape behavior (Weitzner et al., 2015) but impedes the testing of non-naive animals in subsequent maze experiments. It alleviates deficits resulting from sex differences, age, lesions or drug administration (Wagner, 2013).
The mechanism of the animals' inattention to the hidden platform is not known. It is generally recognized that navigation from one location to another can be achieved using a variety of distinct strategies that rely upon different forms of interoceptive or exteroceptive cues, as was evident in the earliest laboratory studies on complex maze learning in the rat. In the first exposition to water maze task, egocentric navigation is characterized by the ability to locate places using proximal and internal cues, including limb movements to estimate speed and heading to estimate direction. Tactile perception is essential for fine motor control, and contributes to a sense of self (Tan et al., 2014; Paolucci et al., 2015; Dominici et al., 2009). We propose that the egocentric navigation task in the first exposition to swimming distracts the attention of animals from the touch sensation.

We hypothesize that tactile inattention would correlate with anxious behavior in rats. Rats whose behavior reflects different levels of anxiety are the translational models of human anxiety disorders. Gustavson and colleagues (2017) found stronger attention distraction in people with heightened anxiety. As a model of different anxious behaviors in water we chose to compare jumping and 
non-jumping rat groups in the original water test, namely "Extrapolation Escape Task" (EET) (Bondarenko, 1980; Rayevsky et al., 1990). In that test, a rat is placed for up to two minutes inside a cylinder, the lower edge of which is lowered into the water. Rats therefore are exposed to two stressors: cold water and restraint in the cylinder. After water immersion, some rats ("jumping rats"; JR) try to jump on the wall of the cylinder. This is a display of the natural tendency of anxious rats to avoid the water (Bondarenko \& Bondarenko, 2014; Javelot, 2011). But the cylinder has a high wall and the rats' jumping behavior is ineffective. The rats can then dive under the water to escape from the cylinder. Other rats ("non-jumping rats"; NJR) dive without any preliminary jumping. In preliminary research, it was found that the JR may be used as an animal model of trait anxiety (Bondarenko \& Bondarenko, 2014). Typical behavior of JR and NJR in the EET is illustrated in the Supplementary online materials ( $\underline{\mathrm{SOM}})$. We propose that the JR will demonstrate a more pronounced EET-induced tactile inattention compared to the NJR.

In water maze experimental protocols, animals are usually exposed to water with a temperature of $+24^{\circ} \mathrm{C}$ from 4 to 6 minutes. Hypothermia-induced analgesia is a very obvious effect of that procedure (Yesilyurt et al., 2015). Forced swim stress-induced nociception alterations in rats are usually shown by tail withdrawal assays (Spradley et al., 2012). Adult rats swimming in a water tank use only their back legs (Clarac et al., 1998). Diving under the lower edge of the cylinder in the EET is a $3 \mathrm{D}$ spatial underwater swimming behavior also involving only the back legs (see $\underline{\mathrm{SOM}}$ ). That is a novel two-legged locomotion for swimming-naïve laboratory-housed albino rats (Bondarenko, 2013; Stryjek et al., 2012). Paolucci and colleagues demonstrated that the same tactile skin receptors react both to skin tension during the movement of the animal and to touch. That is, they form both the locomotor scheme of the body and the representation of the surrounding space (Paolucci et al., 2015). We propose that the skin of the rats' back legs is more sensitive than the tail skin to tactile inattention induced by the swimming locomotion task. To measure the effect of water on the rats' tactile reactivity, we used the Randall-Selitto paw pressure test that was developed as a tool to assess response thresholds to mechanical pressure stimulation; it is often considered a measure of nociception modulation (Randall \& Selitto, 1957). This test involves applying an increasing mechanical force to the surface of the paw until withdrawal occurs (paw withdrawal, PW threshold).

We hypothesize that the jumping behavior as such would not contaminate the nociception threshold of the back legs for the following reason: a water-escaping jumping behavior includes an active fore paw motion (see $\underline{\mathrm{SOM}}$ ). This behavior is a typical land-based type of locomotion. We propose that the automatic jumping behavior is not a case of swim-induced nociception alterations.

We compared the effect on the rats' tactile reactivity of several water immersion experimental conditions that were close to the water maze paradigms in some crucial aspects, but did not involve the spatial orienting task. The conditions included the regular EET paradigm (cognitive task other than navigation and no forced swimming) and EET combined with a FS paradigm (forced swimming and still no navigation task). The possible role of the training factor in tactile inattention was studied by comparing the single and multiple EET expositions.

\section{Method}

\section{Subjects}

The work was performed on 93 male Wistar rats ("Stolbovaya" farm) weighing 220-250 grams, in standard vivarium conditions with free access to food, water and natural light. The rats had never before fallen into the water.

\section{Design}

Before the procedure, the rats were randomly divided into five experimental groups, described below.

1. EET-1 $(n=25)$ : the first exposition to the EET. To evaluate the role of the physical load factor, the number of jumps (the most energy-consuming form of behavior) was recorded in EET-1;

2. EET-1+FS $(n=16)$. To assess the role of the water stress-induced depressive-like behavior in tactile inattention, we use a forced swim (FS) paradigm. The forced swim test is based on the progressive immobility a rodent displays when immersed in a beaker filled with water from which no escape is possible. After the rat dives in the EET equipment, the cylinder was removed and the animal was left to swim for 10 minutes in the tank to form a depressive-like immobile behavior. Immobility (i.e., floating) was defined as the lack of movements except those that will aid in keeping the animal's head above water (Porsolt et al., 1977).

3. Passive control $(n=30)$ : 10 minutes exposure to the dry tank.

4. Active control $(n=10)$ : Rats were placed for 10 minutes in the water tank (to a height of $5 \mathrm{~cm}$., which does not force them to swim) at a temperature of $24^{\circ} \mathrm{C}$ for exposure to the physical factors of water. In the "active" and "passive" control groups, an EET for JR and NJR post hoc classification was carried out 24 hours after the dry tank or the water tank exposition.

5. EET-5 $(n=10)$. To assess the role of the training factor in tactile inattention, rats were placed in EET four times at intervals of 24 hours. Then, 24 hours after EET-4, the rats were exposed to EET-5 for a subsequent PW threshold measure.

\section{Equipment}

We used "Extrapolation Escape Task" (EET) equipment made by Open Science. The Randall-Selitto paw pressure test was performed using an analgesimeter (Ugo Basile).

\section{Procedure}

All experiments took place in winter between the hours of 11.00 and 13.00 .

Using the paw pressure test we registered (in conventional units) the threshold strength of the hard cone tip's pressure on the surface of a hind paw of the animal, causing paw withdrawal (PW). The arithmetic mean of the data values for the first measurements of each animal's right and left paws was used. The baseline level of PW $\left(\mathrm{PW}_{0}\right)$ was determined 30 minutes before the start of the experiment. 
In the EET test, a rat was placed for up to two minutes inside a cylinder with a diameter of $10 \mathrm{~cm}$, the lower edge of which was lowered into the water $\left(24^{\circ} \mathrm{C}\right)$ to a depth of $2.5 \mathrm{~cm}$. for up to two minutes. The height of the water column is $25 \mathrm{~cm}$. in a water tank with a diameter of $60 \mathrm{~cm}$. Immediately after diving, the rats were removed from the water. According to Bondarenko (1980), $80 \%$ of the animals dive up to 20 seconds after water immersion and escape hypothermia. We registered the number of attempts to jump out from the water before diving. Two rats did not dive in EET within two minutes and were eliminated from the experiment. After that, all animals were divided into jumping rats (JR) and non-jumping rats (NJR) subgroups.

The water immersion's antinociceptive effect continues for some time after water stress termination (Abdelhamid et al., 2013). Therefore, the PW test was performed twice. The first test $\left(\mathrm{PW}_{1}\right)$ was immediately after extraction of the animal from the water in EET. PW was used to assess the nociception threshold induced by the interaction of locomotor and tactile tasks. Then the rat was placed for 15 seconds in a home cage for restoring land-based locomotion, and after that $\mathrm{PW}_{2}$ (the only water stress-induced nociception) was measured (Spradley et al., 2012; Hough, 2014). A PW change $\left(\mathrm{PW}_{\mathrm{C} 1}=\mathrm{PW}_{1}-\mathrm{PW}_{0}\right.$ and $\mathrm{PW}_{\mathrm{C} 2}=\mathrm{PW}_{2}-\mathrm{PW}_{0}$ ) was calculated for each animal.

\section{Statistical Analysis}

Because of the small number of animals in some groups, nonparametric methods of statistical analysis were used (Chang, 2003): the Kruskal-Wallis test for distribution equality of $\mathrm{PW}_{\mathrm{C} 1}$ and $\mathrm{PW}_{\mathrm{C} 2}$ across groups, the MannWhitney $U$ test for statistical comparison of $\mathrm{PW}_{\mathrm{C}}$ data in the JR and NJR groups, and the Kendall rank correlation coefficient was calculated between the $\mathrm{PW}_{\mathrm{C}}$ and number of jumps in the EET-1 group and between the $\mathrm{PWc}_{1}$ and the immobility duration for the EET $-1+\mathrm{FS}$ group. The p-level was adjusted with Bonferroni correction for multiple comparisons to handle the multiple testing problem $(\alpha=.05 / 4=.0125)$.

\section{Results}

The descriptive statistics of the $\mathrm{PW}_{0}, \mathrm{PW}_{1}$ and $\mathrm{PW}_{\mathrm{Cl}}$ in every experimental and control group and post hoc subgroup are presented in Table 1.

The Kruskal-Wallis test showed no significant change of $\mathrm{PW}_{\mathrm{C} 2}$ across experimental groups $(H(4)=0.053, p=.974)$. For $\mathrm{PW}_{1}$ and $\mathrm{PW}_{\mathrm{Cl}}$, the null hypothesis that results for all experimental groups come from the same distribution was rejected $(H(4)=12.997, p=.002 ; H(4)=36.69, p<.001)$. Therefore, pairwise comparisons were conducted between the passive control group and every other group (see Table 1).

The Kruskal-Wallis test showed inequality of experimental conditions for both the NJR $(H(4)=9.65, p=.047)$ and JR $(H(4)=25.86, p<.001)$ subgroups of animals. Pairwise comparisons were then conducted between the results of each subgroup in the passive control condition and every other condition. The results of the pairwise conditions are presented in Figure 1.

\section{Discussion}

We found no significant change of $\mathrm{PW}_{\mathrm{C} 2}$ in all animals. This contradicts the data that show swim stress nociception decreases in rats in the tail withdrawal assay (Spradley et al., 2012). It is well established that a tail flick response is mediated by spinal neuronal mechanisms but a paw flick response is mediated by supraspinal ones (Deuis, Dvorakova, \& Vetter, 2017). So the technical and conceptual

Table 1. The Effect of the Experimental Condition on $\mathrm{PW}_{0}, \mathrm{PW}_{1}$ and $\mathrm{PW}_{\mathrm{C} 1}$ in $\mathrm{JR}$ and NJR Animal Subgroups

\begin{tabular}{|c|c|c|c|c|c|c|c|c|c|c|c|c|c|c|}
\hline \multirow{2}{*}{ Group } & \multirow{2}{*}{$\begin{array}{l}\text { Sub- } \\
\text { group }\end{array}$} & \multirow{2}{*}{$n$} & \multicolumn{4}{|c|}{$\mathrm{PW}_{0}$} & \multicolumn{4}{|c|}{$\mathrm{PW}_{1}$} & \multicolumn{4}{|c|}{$\mathrm{PW}_{\mathrm{c} 1}$} \\
\hline & & & $M d$ & $Q_{1}$ & $Q_{3}$ & $p$ & $M d$ & $Q_{1}$ & $Q_{3}$ & $p$ & $M d$ & $Q_{1}$ & $Q_{3}$ & $p$ \\
\hline \multirow{3}{*}{$\begin{array}{l}\text { passive } \\
\text { control }\end{array}$} & $\mathrm{JR}$ & 19 & 4.8 & 3.5 & 6.0 & - & 4.5 & 4.0 & 6.3 & - & 0.0 & -1.0 & +1.0 & - \\
\hline & NJR & 11 & 5.0 & 3.8 & 5.5 & - & 5.5 & 5.0 & 5.5 & - & +0.5 & 0.0 & +0.5 & - \\
\hline & Total & 30 & 5.0 & 3.0 & 5.0 & - & 5.3 & 4.3 & 5.5 & - & 0.0 & -1.6 & +1.0 & - \\
\hline \multirow{3}{*}{$\begin{array}{l}\text { active } \\
\text { control }\end{array}$} & $J R$ & 5 & 4.5 & 4.0 & 5.0 & 1.000 & 4.5 & 4.5 & 5.5 & .602 & +0.2 & -0.5 & +1.0 & .676 \\
\hline & NJR & 5 & 5.0 & 4.5 & 5.8 & .175 & 5.3 & 4.5 & 5.5 & .582 & +0.5 & 0.0 & +0.5 & .754 \\
\hline & Total & 10 & 4.8 & 4.0 & 5.8 & 1.000 & 4.5 & 4.5 & 5.5 & .807 & +0.5 & -0.5 & +0.8 & .880 \\
\hline \multirow{3}{*}{ EET-1 } & JR & 19 & 4.5 & 3.5 & 5.5 & .963 & 6.5 & 6.0 & 9.0 & .033 & $+2.5^{\star}$ & +2.0 & +4.5 & .008 \\
\hline & NJR & 6 & 5.0 & 4.0 & 5.5 & .465 & $5.0^{+}$ & 5.0 & 5.5 & 1.000 & $0.0^{+}$ & 0.0 & +0.5 & .347 \\
\hline & Total & 25 & 4.7 & 4.5 & 5.5 & .468 & $6.3^{*}$ & 5.5 & 7.0 & .006 & +2.2 & +1.5 & +2.8 & .058 \\
\hline \multirow{3}{*}{ EET-5 } & $J R$ & 5 & 4.5 & 3.5 & 5.0 & 1.000 & 3.0 & 2.5 & 3.8 & .016 & $-0.5^{\star}$ & -1.0 & 0.0 & .003 \\
\hline & NJR & 5 & 4.5 & 3.0 & 5.5 & .784 & $3.0^{*}$ & 2.5 & 3.7 & .009 & $-1.0^{*}$ & -0.5 & 0.0 & .011 \\
\hline & Total & 10 & 4.9 & 3.5 & 5.5 & 1.000 & $3.0^{\star}$ & 2.5 & 3.7 & $<.001$ & $-0.5^{\star}$ & -0.5 & 0.0 & .010 \\
\hline \multirow{3}{*}{$\mathrm{EET}-1+\mathrm{FS}$} & $J R$ & 11 & 4.5 & 4.0 & 5.5 & 1.000 & $9.0^{*}$ & 6.5 & 12.5 & .002 & $+7.0^{*}$ & +3.0 & +11.5 & .012 \\
\hline & NJR & 5 & 5.0 & 3.0 & 5.0 & 1.000 & $4.0^{+}$ & 4.0 & 5.0 & .117 & $+1.0^{+}$ & 0.0 & +1.0 & .296 \\
\hline & Total & 16 & 5.2 & 5.0 & 5.3 & .450 & $8.0^{*}$ & 6.0 & 12.0 & .010 & $+4.0^{\star}$ & +2.0 & +9.0 & .006 \\
\hline
\end{tabular}

Notes: $\quad$ Data are presented in the form of medians, lower and upper quartile values and $p$-values for comparisons 


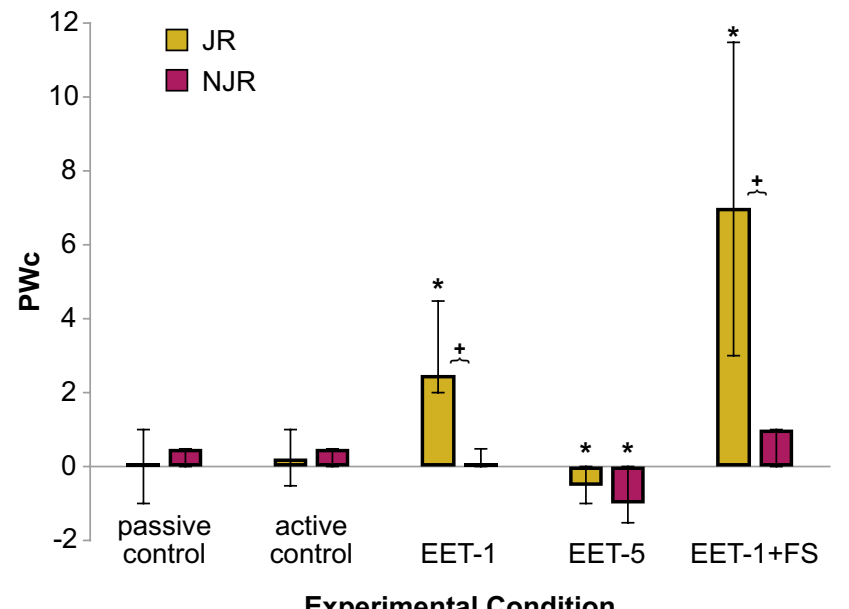

Experimental Condition

Figure 1. Effect of experimental conditions on $P W_{\mathrm{C} 1}$ of $\mathrm{JR}$ and NJR subgroups of rats. Data are presented in the form of medians with the values of the lower and upper quartiles; * $p<.0125$ to the passive control; ${ }^{+} p<.05$ for JR/NJR comparisons.

factors may be critical in observing this relationship, including the type and intensity of task demand and the degree of temporal overlap between task and pain processing (Buhle \& Wager, 2010).

There was no significant modification of $\mathrm{PW}_{\mathrm{C} 1}$ in the active control compared to the passive control groups of animals (see Figure 1). We propose that neither novelty nor the physical impact of the water immersion (cold stress, water sensation) influence the rats' paw tactile reactivity.

The distraction model assumes that the subject directs limited attention resources to a competing perception or task, putting pain in the background (Bradshaw et al., 2012; Petrovic et al., 2000). Gustavson and colleagues (2017) found strong problems with task switching in people with heightened anxiety. We found that $\mathrm{PW}_{\mathrm{C} 1}$ was increased above the passive control baseline in highly anxious animals (JR) only in the EET-1 and EET-1+FS groups. We assume that water locomotion induces the nociception threshold increase in JR, and that switching from the more attentionally demanding task to the less demanding task was difficult for animals with higher levels of trait anxiety.

Correlations between the number of jumps in EET-1 and $\mathrm{PW}_{\mathrm{C} 1}(\tau=.031, p=.465)$, and between the duration of immobility in the FS and $\mathrm{PW}_{\mathrm{C} 1}(\tau=.029, p=.435)$ were not significant. This excludes the influence of the jumping locomotion and the immobility behavior on rat paw tactile reactivity. We propose that swimming with only the hind limbs is a distractor for tactile attention in water-naive JR.

We found a significant decrease in $\mathrm{PW}_{\mathrm{C} 1}$ in preliminarily trained JR and NJR rats of the EET -5 group. It may be a redundancy which was observed in Pavlovian "signal and outcome" trained rats (Utochkin, 2010). Nonetheless, we previously found that diving in EET trained rats is a goal-directed behavior but not a "signal" behavior (Bondarenko, 2013; 2014). We also observed a diving locomotion acquisition in EET trained rats (see SOM). So, the diving skill may decrease the distractor properties of water locomotion as a special object of the animal's attention. Therefore, EET training rather than training within the same set-up might be recommended to improve rodent performance in water navigation tests.

\section{Conclusions}

In summary, our results agree with the hypothesis that the water locomotion task influences a rat's tactile sensitivity. We found this effect to be more pronounced in rats with higher levels of trait anxiety and suggest that it reflects difficulties in switching from the more attentionally demanding task to the less demanding task in such rats. We also found that the paw flick test may be a useful model for studies of attention distracting in rats, and propose that EET training improves the hidden platform detection in animal water navigation tests.

\section{References}

Abdelhamid, R.E., $\quad$ Kovacs, K. J., $\quad$ Pasley, J. D., $\quad$ Nunez, M. G., \& Larson, A. A. (2013). Forced swim-induced musculoskeletal hyperalgesia is mediated by CRF2 receptors but not by TRPV1 receptors. Neuropharmacology, 72, 29-37. doi:10.1016/j.neuropharm.2013.04.016

Bondarenko, N.A. (2013). Izuchenie vozmozhnosti formirovaniia tselenapravlennogo povedeniya u krys s "odnoi proby" $\mathrm{v}$ teste "Ekstrapoliatsionnoe izbavlenie" [Study of possibility to form goal-directed behavior in one trial in "Extrapolation Escape Task" test in rats]. In A.N. Kharitonov (Ed.), Evoliutsionnaya i sravnitelnaya psikhologiya $v$ Rossii: traditsii $i$ perspektivy [Evolutionary and comparative psychology in Russia: Traditions and perspectives] (pp.122-130). Moscow: IP RAS. (In Russian).

Bondarenko, N.A. (1980). Zavisimost realizatsii povedeniya izbavleniya iz ostroi stressogennoi situatsii ot tipologicheskoi prinadlezhnosti zhivotnykh [Relationship between escape behavior from acute stress and animal typological traits]. Dep. VINITI № 2038-1980 g. (In Russian)

Bondarenko, N.A. (2014). "GDE?" i “KAK?" v tselenapravlennom poiskovom povedenii krys [Where and How in goal-directed search behavior in rats]. In Proceedings of the Sixth International Conference on Cognitive Science, 23-27.06.2014, Kaliningrad, Russia (pp. 169-171). Kaliningrad. (In Russian).

Bondarenko, N. A., \& Bondarenko, N.A. (2014). Individualnye razlichiya povedeniya krys $\mathrm{v}$ teste "Ekstrapolyatsionnoe izbavlenie": vozmozhnost vyyavleniya "trevozhnogo" fenotipa [Individual differences in rat behavior in the "Extrapolation Escape Task" test: possibility to reveal the "axious" phenotype]. In Innovatsii v farmakologii: ot teorii $k$ praktike [Abstracts of the conference "Innovations in Pharmacology: From Theory to Practice", Saint Petersburg, Russia, October 27-28, 2014] (pp. 28-30). Saint-Petersburg: "Alta Astra". (In Russian).

Bradshaw, D.H., Chapman, R., Jacobson, R.C., \& Donaldson, G. W. (2012). Effects of music engagement on responses to painful stimulation. The Clinical Journal of Pain, 28(5), 418-427. doi:10.1097/ajp.0b013e318236c8 ca

Buhle, J., \& Wager, T.D. (2010). Performance-dependent inhibition of pain by an executive working memory task. Pain, 149(1), 19-26. doi:10.1016/j.pain.2009.10.027

Chang, Y.H. (2003). Biostatistics 101: Data presentation. Singapore Medical Journal, 44(6), 280-285. Retrieved from https://pdfs.semanticscholar.org/11e9/2bea7d503eeeac6e8e 89d27fc13 c840e43ff.pdf.

Deuis, J.R., Dvorakova, L. S., \& Vetter, J. (2017). Methods used to evaluate pain behaviors in rodents. Frontiers in Molecular Neuroscience, 10(284), 1-17. doi:10.3389/fnmol.2017.00284

Dominici, N., Daprati, E., Nico, D., Cappellini, G., Ivanenko, Y.P., \& Lacquaniti, F. (2009). Changes in the limb kinematics and walking-distance estimation after shank elongation: Evidence for a locomotor body schema? Journal of Neurophysiology, 101(3), 1419-1429. ㅁoi:10.1152/ jn. 91165.2008 
Drugan, R. C., Christianson, J.P., Warner, T. A., \& Kent, S. (2013). Resilience in shock and swim stress models of depression. Frontiers in Behavioral Neuroscience, 7(14), 1-8. doi:10.3389/ fnbeh.2013.00014

Gustavson, D.E., $\quad$ Altamirano, L. J., Johnson, D. P., Whisman, M.A., \& Miyake, A. (2017). Is set shifting really impaired in trait anxiety? Only when switching away from an effortfully established task set. Emotion, 17(1), 88-101. doi:10.1037/emo0000212

Hough, L. B., Nalwalk, J. W., Yang, W., \& Ding, X. (2014). Significance of neuronal cytochrome $\mathrm{P} 450$ activity in opioid-mediated stress-induced analgesia. Brain Research, 1578, 30-37. doi:10.1016/j.brainres.2014.07.007

Javelot, H., Weiner, L., Terramorsi, R., Rougeot, C., Lalonde, R., \& Messaoudi, M. (2011). Efficacy of chronic antidepressant treatments in a new model of extreme anxiety in rats. Depression Research and Treatment, 2011, 1-10. doi:10.1155/2011/531435

Ježek, K., Lee, B. B., Kelemen, E., McCarthy, K. M., McEwen, B.S., \& Fenton, A. A. (2010). Stress-induced out-of-context activation of memory. PLoS Biology, 8(12), e1000570. doi:10.1371/ journal.pbio. 1000570

de Kloet, E.R., \& Molendijk, M.L. (2016). Coping with the forced swim stressor: Towards understanding an adaptive mechanism. Neural Plasticity, 2016(2016), 6503162: 1-13. doi:10.1155/2016/6503162

Paolucci, T., Piccinin, G., $\quad$ Paolucci, S., Spadini, E., Saraceni, V.M., \& Morone, G. (2015). Tactile and proprioceptive sensory stimulation modifies estimation of walking distance but not upright gait stability: A pilot study. Journal of Physical Therapy Science, 27(10), 3287-3293. doi:10.1589/ jpts. 27.3287

Petrovic, P., Petersson, K. M., Ghatan, P.H., Stone-Elander, S., \& Ingvar, M. (2000). Pain-related cerebral activation is altered by a distracting cognitive task. Pain, 85(1), 19-30. doi:10.1016/s0304-3959(99)00232-8

Porsolt, R.D., Le Pichon, M., \& Jalfre, M. (1977). Depression: A new animal model sensitive to antidepressant treatments. Nature, 266(5604), 730-732. doi:10.1038/266730a 0

Randall, L. O., \& Selitto, J. J. (1957). A method for measurement of analgesic activity on inflamed tissue. Archives Internationales de Pharmacodynamie et de Therapie, 111(4), 409-419.

Rayevsky, K.S., Bondarenko, N.F., Kudrin, V.S., \& Mirosnichenko, I. I. (1990). Cognitive deficiency induced by the acute stress in rats: A possible role of brain catecholaminergic systems. Annali dell'Istituto Superiore di Sanità, 26(1), 25-30. Retrieved from http://www.iss.it/binary/publ/cont/ Pag25 30Vol26N11990.pdf.
Sandi, C., Loscertales, M., \& Guaza, C. (1997). Experience-dependent facilitating effect of corticosteroneon spatialmemoryformation in the water maze. European Journal of Neuroscience, 9(4), 637-642. doi:10.1111/j.1460-9568.1997.tb01412.x

Spradley, J. M., Davood, A., Carstens, M.I., \& Carstens, E. (2012). Effects of acute stressors on itch- and pain-related behaviors in rats. Pain, 153(9), 1890-1897. doi:10.1016/j. pain.2012.05.032

Stryjek, R., Modlińska, K., \& Pisula W (2012). Species specific behavioural patterns (digging and swimming) and reaction to novel objects in wild type, wistar, sprague-dawley and brown norway rats. PLoS ONE, 7(7), e40642: 1-10. doi:10.1371/journal.pone.0040642

Tan, D.W., $\quad$ Schiefer, M.A., $\quad$ Keith, M.W., $\quad$ Anderson, J.R., Tyler, J., \& Tyler, D. J. (2014). A neural interface provides long-term stable natural touch perception. Science Translational Medicine, 6(257), 257ra138:1-12. doi:10.1126/ scitranslmed.3008669

Utochkin, I.S. (2010). [Distractor effects in perceptual tasks]. Psychological Journal, 31(3), 25-32. (In Russian).

Vorhees, C. V., \& Williams, M. T. (2016). Cincinnati water maze: A review of the development, methods, and evidence as a test of egocentric learning and memory. Neurotoxicology and Teratology, 57(2016), 1-19. doi:10.1016/j.ntt.2016.08.002

Wagner, A. K., W. Brayer, S. B., Hurwitz, M., Niyonkuru, C., Zou, H., Failla, M., Patricia Arenth, A., Manole, M. D., Skidmore, E., \& Thiels, E. (2013). Non-spatial pre-training in the water maze as a clinically relevant model for evaluating learning and memory in experimental TBI. Neurobiology of Learning and Memory, 106(2013), 71-86. doi:10.1016/j. nlm.2013.07.006

Weitzner, D.S., Engler-Chiurazzi, E.B., Kotilinek, L.A., Ashe, K.H., \& Morris, R. (2015). Morris Water Maze Test: Optimization for mouse strain and testing environment. Journal of Visualized Experiments, 100, e52706: 1-11. doi: $10.3791 / 52706$

Yesilyurt, O., Seyrek, M., Tasdemir, S., Kahraman, S., Deveci M. S. Karakus, E., Halici, Z., \& Dogrul, A. (2015). The critical role of spinal 5-HT receptors in opioid and non-opioid type stress-induced analgesia. European Journal of Pharmacology, 762, 402-410. doi:10.1016/j.ejphar.2015.04.020 


\title{
Тревожность
}

и проблема тактильной

«невнимательности»

\section{Животных в водных тестах}

\author{
Нина Бондаренко \\ Фонд «Развитие фармакологии эмоционального стресса», Красногорск, Россия
}

\begin{abstract}
Аннотация. «Невнимательность» животных, впервые попавших в воду, к тактильным стимулам осложняет обнаружение «спасительной платформы» в тестах Морриса, Цинциннати и др., что, в свою очередь, нарушает способность животных к обучению навигации в этих тестах. Выявление причин тактильной «невнимательности» животных является актуальным для оптимизации процедуры эксперимента. В настоящей работе для оценки внимания крыс к тактильным стимулам регистрировали пороговое значение силы тактильного воздействия, вызывающего моторную реакцию отдергивания задней лапы. В качестве локомоторной задачи крысам предлагалось поднырнуть под стенкой цилиндра, нижним концом опущенного в воду (тест «Экстраполяционное избавление», ТЭИ). Обнаружено, что только локомоторная задача подныривания в ТЭИ, но не факторы новизны, уровня мотивации, погружения в воду или физической нагрузки снижали реактивность высокотревожных животных на тактильные стимулы. Этот эффект не наблюдался у крыс, обученных подныриванию в ТЭИ. Можно предположить, что у крыс, как и у людей, способность к переключению с более сложной задачи на более простую (в нашем случае с подныривания на отдергивание лапы) зависит от уровня тревожности.
\end{abstract}

Контактная информация: Нина Бондаренко, bondarenko52nina@gmail.com; 143444, Московская обл., г. Красногорск, мкр. Опалиха, ул. Счастливая, 32.

Ключевые слова: крысы, тест «Экстраполяционное избавление», тактильные рецепторы, схема тела, локомоторная задача, дистракторы, ингибирование, тревожность

(c) 2017 Нина Бондаренко. Данная статья доступна по лицензии Creative Commons "Attribution” («Атрибуция») 4.0. всемирная, согласно которой возможно неограниченное распространение и воспроизведение этой статьи на любых носителях при условии указания автора и ссылки на исходную публикацию статьи в данном журнале в соответствии с канонами научного цитирования.

Статья поступила в редакцию 17 октября 2017 г. Принята к печати 26 декабря 2017 г.

\section{Литература}

Бондаренко Н.А. Изучение возможности формирования целенаправленного поведения у крыс с «одной пробы» в тесте «Экстраполяционное избавление» // Эволюционная и сравнительная психология в России: традиции и перспективы / Под ред. А.Н. Харитонова. М.: Институт психологии РAH, 2013. С. $122-130$.

Бондаренко Н.А. Зависимость реализации поведения избавления из острой стрессогенной ситуации от типологической принадлежности животных. М.: Деп. в ВИНИТИ № 2038-1980 г., 1980 .

Бондаренко Н.А. «ГДЕ?» и «КАК?» в целенаправленном поисковом поведении крыс // Шестая международная конференция по когнитивной науке, Калининград, Россия, 23-27.06.2014. М.: ИП PAН, 2014. С. 169-171. URL: www. openscience.ru/download.php?filename=bondarenko tei 03.pdf.
Бондаренко Н. А., Бондаренко Н.А. Индивидуальные различия поведения крыс в тесте «экстраполяционное избавление»: возможность выявления «тревожного» фенотипа // Инновации в фармакологии: от теории к практике, СанктПетербург, 27-28 октября 2014 года. Тезисы конференции. СПб.: Альта Астра, 2014. С. 28-30.

Уточкин И.С. Эффекты дистрактора в перцептивных задачах // Психологический журнал. 2010. Т. 31. № 3. С. 25-32.

Abdelhamid R.E., Kovacs K.J., Pasley J.D., Nunez M. G., Larson A. A. Forced swim-induced musculoskeletal hyperalgesia is mediated by CRF2 receptors but not by TRPV1 receptors // Neuropharmacology. 2013. Vol. 72. P. 29-37. doi:10.1016/j. neuropharm.2013.04.016

Bradshaw D.H., Chapman R., Jacobson R.C., Donaldson $G$. W. Effects of music engagement on responses to painful stimulation // The Clinical Journal of Pain. 2012. Vol. 28. No. 5. P. 418-427. doi:10.1097/ajp.0b013e318236c8ca 
Buhle J., Wager T.D. Performance-dependent inhibition of pain by an executive working memory task // Pain. 2010. Vol. 149. No. 1. P. 19-26. doi:10.1016/j.pain.2009.10.027

Chang Y.H. Biostatistics 101: Data presentation // Singapore Medical Journal. 2003. Vol. 44. No.6. P. 280-285. URL: https://pdfs.semanticscholar.org/11e9/2bea7d503eeeac6e8e89d2 7fc13 c840e43ff.pdf.

Deuis J.R., Dvorakova L.S., Vetter J. Methods used to evaluate pain behaviors in rodents // Frontiers in Molecular Neuroscience. 2017. Vol. 10. No. 284. P. 1-17. doi:10.3389/fnmol.2017.00284

Dominici N., Daprati E., Nico D., Cappellini G., Ivanenko Y.P., Lacquaniti F. Changes in the limb kinematics and walking-distance estimation after shank elongation: Evidence for a locomotor body schema? // Journal of Neurophysiology. 2009. Vol. 101. No. 3. P. 1419-1429. doi:10.1152/in.91165.2008

Drugan R. C., Christianson J.P., Warner T.A., Kent S. Resilience in shock and swim stress models of depression // Frontiers in Behavioral Neuroscience. 2013. Vol. 7. No. 14. P. 1-8. doi:10.3389/ fnbeh.2013.00014

Gustavson D.E., Altamirano L.J., Johnson D.P., Whisman M. A., Miyake A. Is set shifting really impaired in trait anxiety? Only when switching away from an effortfully established task set // Emotion. 2017. Vol. 17. No.1. P. 88-101. doi:10.1037/ emo0000212

Hough L. B., Nalwalk J.W., Yang W., Ding X. Significance of neuronal cytochrome P450 activity in opioid-mediated stressinduced analgesia // Brain Research. 2014. Vol. 1578. P. 30-37. doi:10.1016/j.brainres.2014.07.007

Javelot H., Weiner L., Terramorsi R., Rougeot C., Lalonde R., Messaoudi M. Efficacy of chronic antidepressant treatments in a new model of extreme anxiety in rats // Depression Research and Treatment. 2011. P. 1-10. doi:10.1155/2011/531435

Ježek K., Lee B.B., Kelemen E., McCarthy K.M., McEwen B.S., Fenton A.A. Stress-induced out-of-context activation of memory // PLoS Biology. 2010. Vol. 8. No.12. P. e1000570. doi:10.1371/journal.pbio.1000570

de Kloet E.R., Molendijk M.L. Coping with the forced swim stressor: Towards understanding an adaptive mechanism // Neural Plasticity. 2016. Vol. 2016. No.2016. P. 6503162: 1-13. doi:10.1155/2016/6503162

Paolucci T., Piccinin G., Paolucci S., Spadini E., Saraceni V.M., Morone G. Tactile and proprioceptive sensory stimulation modifies estimation of walking distance but not upright gait stability: A pilot study // Journal of Physical Therapy Science. 2015. Vol. 27. No. 10. P. 3287-3293. doi:10.1589/jpts.27.3287

Petrovic P., Petersson K.M., Ghatan P.H., Stone-Elander S., Ingvar $M$. Pain-related cerebral activation is altered by a distracting cognitive task // Pain. 2000. Vol. 85. No.1. P. 19-30. doi:10.1016/s0304-3959(99)00232-8
Porsolt R. D., Le Pichon M., Jalfre M. Depression: A new animal model sensitive to antidepressant treatments // Nature. 1977. Vol. 266. No. 5604. P. 730-732. doi:10.1038/266730a0

Randall L.O., Selitto J.J. A method for measurement of analgesic activity on inflamed tissue // Archives Internationales de Pharmacodynamie et de Therapie. 1957. Vol. 111. No. 4. P. 409-419.

Rayevsky K.S., Bondarenko N.F., Kudrin V.S., Mirosnichenko I.I. Cognitive deficiency induced by the acute stress in rats: A possible role of brain catecholaminergic systems // Annali dell'Istituto Superiore di Sanità. 1990. Vol. 26. No. 1. P. 25-30. URL: http://www.iss.it/binary/publ/cont/Pag25 30Vol26N11990.pdf.

Sandi C., Loscertales M., Guaza C. Experience-dependent facilitating effect of corticosterone on spatial memory formation in the water maze // European Journal of Neuroscience. 1997. Vol. 9. No. 4. P. 637-642. doi:10.1111/j.1460-9568.1997.tb01412.x

Spradley J.M., Davood A., Carstens M.I., Carstens E. Effects of acute stressors on itch- and pain-related behaviors in rats // Pain. 2012. Vol. 153. No.9. P. 1890-1897. doi:10.1016/j. pain.2012.05.032

Stryjek R., Modlińska K., Pisula W. Species specific behavioural patterns (digging and swimming) and reaction to novel objects in wild type, wistar, sprague-dawley and brown norway rats // PLoS ONE. 2012. Vol. 7. No.7. P. e40642: 1-10. doi:10.1371/ journal.pone. 0040642

Tan D. W., Schiefer M. A., Keith M. W., Anderson J. R., Tyler J., Tyler D.J. A neural interface provides long-term stable natural touch perception // Science Translational Medicine. 2014. Vol.6. No. 257. P.257ra138:1-12. doi:10.1126/scitranslmed.3008669

Vorhees C. V., Williams M.T. Cincinnati water maze: A review of the development, methods, and evidence as a test of egocentric learning and memory // Neurotoxicology and Teratology. 2016. Vol. 57. No. 2016. P. 1-19. doi:10.1016/i.ntt.2016.08.002

Wagner A.K., W. Brayer S. B., Hurwitz M., Niyonkuru C., Zou H., Failla M., Patricia Arenth A., Manole M.D., Skidmore E., Thiels $E$. Non-spatial pre-training in the water maze as a clinically relevant model for evaluating learning and memory in experimental TBI // Neurobiology of Learning and Memory. 2013. Vol. 106. No. 2013. P. 71-86. doi:10.1016/i.nlm.2013.07.006

Weitzner D.S., Engler-Chiurazzi E.B., Kotilinek L.A., Ashe K. H., Morris R. Morris Water Maze Test: Optimization for mouse strain and testing environment // Journal of Visualized Experiments. 2015. Vol. 100. P. e52706: 1-11. doi:10.3791/52706 Yesilyurt O., Seyrek M., Tasdemir S., Kahraman S., Deveci M.S., Karakus E., Halici Z., Dogrul A. The critical role of spinal 5-HT receptors in opioid and non-opioid type stressinduced analgesia // European Journal of Pharmacology. 2015. Vol. 762. P. 402-410. doi:10.1016/j.ejphar.2015.04.020 